\title{
Perancangan Sistem Informasi Klasifikasi Wortel Berbasis Pengolahan Citra Digital
}

\section{Designing an Information System of Carrot Classification Based on Digital Image Processing}

\author{
Yudha Saintika $^{1 *}$, Aditya Wijayanto ${ }^{2}$, Citra Wiguna ${ }^{3}$ \\ 1,3) Program Studi S1 Sistem Informasi, Fakultas Teknologi Industri dan Informatika \\ 2) Program Studi S1 Rekayasa Perangkat Lunak, Fakultas Teknologi Industri dan Informatika \\ Institut Teknologi Telkom Purwokerto \\ Jl. D. I. Panjaitan No. 128, Purwokerto, Jawa Tengah 53147. Telp. (0281) 641629 \\ *e-mail : yudha@ittelkom-pwt.ac.id
}

\begin{abstract}
ABSTRAK
Penanganan pascapanen berbagai hasil pertanian di Indonesia

Histori Artikel:

Diajukan:

$23 / 08 / 2018$

Diterima:

$31 / 10 / 2018$

Diterbitkan:

$17 / 11 / 2018$ seringkali masih kurang optimal. Padahal untuk memperoleh produk yang berkualitas kegiatan pascapanen merupakan hal yang sangat penting. Salah satu hal yang paling mendasar dalam kegiatan pascapanen adalah pemutuan produk. Pemutuan yang dilakukan dengan pengukuran secara langsung masih memiliki banyak kekurangan. Penelitian ini bertujuan untuk merancang dan mengembangkan suatu sistem informasi yang mampu memperoleh parameter visual dengan objek wortel yang berupa area citra, diameter citra, dan panjang citra. Dengan menggunakan metode korelasi parametrik maka tingkat keeratan hubungan antara parameter visual tersebut dengan parameter hasil pengukuran langsung dapat diketahui sehingga parameter-parameter pengukuran langsung seperti bobot, volume, panjang, dan diameter dapat diperkirakan dari parameter visual wortel. Dari proses pengujian didapatkan bahwa ketiga parameter visual yang didapatkan dengan nilai threshold tertentu mampu menunjukkan tingkat keeratan hubungan yang sangat kuat yaitu berkisar antara 0.900 - 1.000. Kemudian melalui metode korelasi parametrik tingkat keberhasilan klasifikasi kelas wortel diperoleh hingga $98.88 \%$.
\end{abstract}

Kata Kunci: Pemutuan, Sistem Informasi, Parameter Visual, Korelasi Parametrik

\begin{abstract}
The treatment of post-harvesting period in Indonesian agriculture is still considered not in optimal condition. In order to produce good quality crops, post-harvesting period is considered as an important step. One of basic thing in post-harvesting period is product quality measurement. Measurement is held in terms of measuring the size of crops in direct way. The goal of this research is to design and develop an information system which could obtain visual parameters of carrots such as: image area, diameter, and its length. By using parametric correlation method, it is possible to increase the correlation between those visual parameters with direct measurement parameter results that could be recognized. In other word, direct measurement parameter results, such as: weight, volume, length and diameter could be predicted from the carrots' visual parameters. Testing results reflect that those three visual parameters obtained in its current threshold, could show a very strong correlation point, ranging from $0.900-1.000$. Then, by using parametric correlation method, carrots classification success rate obtained reach 98.88 .
\end{abstract}

Keywords : Quality Measurement, Information System, Visual Parameter, Parametric Correlation 


\section{PENDAHULUAN}

Perkembangan tanaman wortel saat ini sudah cukup luas diusahakan oleh petani, hal itu disebabkan karena harganya yang menguntungkan serta dibutuhkan oleh masyarakat secara luas. Permintaan wortel setiap tahunnya di dalam negeri cenderung meningkat. Akan tetapi, pedagang atau petani masih kurang optimal dalam penanganan pasca panen wortel, sehingga produk yang dipasarkan kurang berkualitas (Santosa, 2006). Salah satunya adalah proses pemutuan, dimana proses ini niasanya dilakukan secara visual dengan memperhatikan bentuk fisik, sifat fisik, ukuran buah atau kombinasinya yang dilakukan secara manual dan belum sesuai dengan kriteria SNI (Anggraeni, 2008).

Di desa Purwosari, kecamatan Baturraden, Kabupaten Banyumas, pemutuan wortel dilakukan berdasarkan bobot wortel sehingga pemutuan tersebut belum sesuai dengan kriteria SNI wortel yaitu berdasarkan diameter wortel. Pemutuan juga masih memiliki banyak kekurangan karena sistem visual manusia dapat mengalami kelelahan dan kejenuhan sehingga hasil yang diperoleh tidak konsisten. Oleh karena itu, diperlukan sistem visual yang dapat digunakan untuk proses pemutuan dan pendeteksian kerusakan pada buah-buahan dan sayuran.

Salah satu sistem visual yang telah dipakai adalah teknik pengolahan citra (image processing), dengan memakai sensor elektro optika berbasis pada aplikasi komputer akan diperoleh hasil sortasi yang seragam karena berdasarkan penilaian objektif dan konsisten (Hui et al., 2006). Penggunaan sistem elektro optika ini didasarkan pada kemampuan yang lebih peka dan tepat daripada kemampuan visual manusia dalam menangkap pantulan gelombang elektromagnetik buah yang berubah-ubah akibat perbedaan karakteristik fisik buah (Ahmad, 2005).

Banyak metode yang sebenarnya dapat dilakukan untuk melakukan klasifikasi terhadap citra. Retno dkk (Whidhiasih, Wahanani, \& Supriyanto, 2013) menggunakan metode K-NN dan LDA dalam mengklasifikasikan buah Belimbing. Sedangkan (Wiharja, Yanuar Putu; Harjoko, 2015) menggunakan metode jaringan saraf tiruan untuk mengklasifikasi mutu buah pisang. Penulis menggunakan metode korelasi parametrik dalam penelitian ini karena metode ini dapat mengetahui seberapa erat hubungan antara parameter mutu dan morfologi wortel hasil pengukuran secara langsung dengan parameter visual hasil pengolahan citra. Selain itu dibandingkan dua penelitian sebelumnya tersebut, menurut (Anggraeni, 2008) metode korelasi parametrik dinilai lebih mudah dan cepat untuk digunakan serta terbukti menghasilkan akurasi yang cukup baik. Untuk lebih menghasilkan akurasi yang lebih baik lagi, maka terdapat perbedaan penelitian penulis dengan penelitian sebelumnya yang dilakukan oleh (Anggraeni, 2008) yaitu pada teknik pengolahan citranya. Walaupun objek penelitiannya sama yaitu wortel, namun pengolahan citra wortel pada penelitian tersebut belum mempertimbangkan berbagai posisi wortel sehingga hanya dapat diolah jika citranya tegak lurus atau sejajar. Sedangkan pada penelitian ini perancangan teknik pengolahan citra sudah dirancang sedemikian rupa sehingga dapat mengambil citra wortel dalam posisi apapun baik tegak lurus, miring, maupun memiliki sudut tertentu. Diharapkan setelah dilakukan penelitian ini ditemukan parameter visual hasil pengolahan citra yang dapat mengkelaskan wortel sesuai standar SNI.

Permasalahan yang muncul dalam penulisan penelitian ini antara lain:

1. Bagaimana mengimplementasikan pengolahan citra digital yang berupa proses thresholding dan operasi morfologi untuk mendapatkan parameter visual wortel.

2. Bagaimana mengimplementasikan metode korelasi parametrik untuk mengetahui hubungan antara parameter mutu dan morfologi wortel (diameter, panjang, volume, dan bobot) hasil pengukuran langsung dengan parameter visual hasil pengolahan citra.

3. Bagaimana pengkelasan wortel berdasarkan diameter wortel sesuai syarat SNI dan yang berlaku di lapangan menggunakan pengolahan citra.

Tujuan yang ingin dicapai dalam penelitian ini adalah:

1. Mengimplementasikan pengolahan citra digital untuk mendapatkan parameter visual wortel.

2. Mengkaji hubungan antara parameter mutu dan morfologi wortel (diameter, panjang, volume, dan bobot) hasil pengukuran langsung dengan parameter visual hasil pengolahan citra menggunakan metode korelasi parametrik.

3. Mengkelaskan wortel berdasarkan diameter sesuai syarat SNI menggunakan teknik pengolahan citra digital dan melakukan validasi terhadap hasil penggolongan.

4. Mengetahui pengaruh nilai threshold terhadap tingkat keberhasilan klasifikasi 
dan tingkat keeratan hubungan antara parameter visual hasil pengolahan citra dan parameter hasil pengukuran langsung.

\section{METODE PENELITIAN}

Pada bagian ini akan dijelaskan mengenai teori, langkah-langkah, dan alat maupun bahan yang dibutuhkan untuk melaksanakan penelitian.

\section{A. Standarisasi Kualitas}

Mutu pangan merupakan karakteristik pangan yang dapat diterima oleh konsumen, sehingga pangan bermutu merupakan pangan produk yang memiliki karakteristik tertentu sehingga dapat sesuai dnegan keinginan pelanggan. Mutu produk pangan dipengaruhi oleh:

1. Faktor luar yang dapat terlihat, misalnya warna, penampakan, bentuk, ukuran.

2. Faktor dalam yang tidak dapat terlihat, misalnya rasa, kemanisan, pahit, kesan di mulut atau kandungan gizi.
Standarisasi merupakan fasilitas evaluasi selama transaksi. Dalam mekanisme yang komplek dari pemasaran sayur dan buah, standarisasi dapat memperkecil resiko kerugian pembeli saat memperoleh produk bermutu rendah dengan pembayaran yang tinggi. Beberapa jenis sayuran di Indonesia mempunyai Standarisasi Nasional Indonesia (SNI), standar ini dijadikan sebagai acuan unguk melakukan pengkelasan atau pemutuan produk. Selain mengacu pada SNI, biasanya para petani mempunyai standar sendiri untuk melakukan pemutuan atau pengkelasan pada bauh dan sayuran. Tabel 1 dibawah ini menunjukan standar pemutuan wortel menurut Kriteria SNI

Tabel 1. Standar Pemutuan Wortel Menurut SNI (Soekarto, 1990)

\begin{tabular}{llll}
\hline Karakteristik & \multicolumn{1}{c}{ Cara Pengujian } \\
\cline { 2 - 3 } $\begin{array}{lll}\text { Keasaman sifat varietas } \\
\text { Kekerasan }\end{array}$ & Mutu I & Mutu II & organoleptik \\
Warna & seragam & seragam & organoleptik \\
Kerataan permukaan & keras & keras & organoleptik \\
Tekstur & normal & normal & organoleptik \\
Kerusakan (\%) & tidak mengayu & tidak mengayu & organoleptik \\
Gumlah/jumlah) maks busuk (\%) & 5 & 5 & SP-SMP-310-1981 \\
Gumlah/jumlah) maks busuk(\%) & 2 & & \\
$\begin{array}{l}\text { Diameter(mm) } \\
\text { Tangkai daun(cm) }\end{array}$ & $31-50$ & 2 & SP-SMP-311-1981 \\
Kotoran & maks 5 & $15-30$ & SP-SMP-309-1981 \\
\end{tabular}

\section{B. Pengolahan Warna}

Untuk melakukan pemrosesan citra, pengolahan citra sangatlah penting. Pada tugas akhir ini terdapat tiga pemodelan warna yang digunakan, yaitu :

\section{RGB}

Model warna RGB adalah salah satu model warna aditif yaitu suatu warna dibentuk dengan mengkombinasikan energi cahaya dari ketiga warna pokok dalam berbagai perbandingan. Model warna RGB didasarkan pada pembentukan warna melalui kombinasi ketiga warna pokoknya, yaitu merah, hijau, dan biru untuk merepresentasikan suatu warna.

2. Grayscale

Derajat Keabuan Citra adalah representasi citra dengan hanya menggunakan satu warna gray (abu-abu) yang berbeda intensitasnya. Citra abu-abu dapat dihasilkan dari citra warna $R G B$ dengan mengalikan tiga komponen warna pokok merah, hijau, dan biru dengan suatu koefisien yang jumlahnya satu.

$$
L o=w r R+w g G+w b B
$$

Berdasarkan NTSC (National Television Sistem Committee), dimana :

$$
\begin{aligned}
& \mathrm{wr}=0.299 \\
& \mathrm{wg}=0.587 \\
& \mathrm{wb}=0.144
\end{aligned}
$$

Penggunaan grayscale ini dikarenakan tidak banyak data yang dibutuhkan pada setiap pikselnya. Intensitas grayscale biasanya disimpan sebagai data citra 8 bit atau 256 intensitas warna gray dari nilai 0 (hitam) dan 255 (putih) sedangkan nilai untuk 
warna abu-abu berada diantaranya. Grayscale image lebih simpel dalam pengolahan data dibandingkan pengolahan menggunakan citra dengan warna sebenarnya (truecolor image) (Ahmad, 2005).

3. Black and White

Citra biner (binary image) adalah citra yang hanya mempunyai dua nilai derajat keabuan yaitu hitam dan putih[. Alasan masih digunakannya citra biner dalam pengolahan citra digital hingga saat ini adalah algoritma untuk citra biner telah berkembang dengan baik dan waktu pemrosesan lebih cepat karena jumlah bit untuk tiap pikselnya lebih sedikit.

\section{Thresholding}

Menurut (Ahmad, 2005), thresholding adalah operasi non-linier yang mengubah gambar gray-scale atau citra berderajat keabuan menjadi citra biner atau hitam putih sehingga dapat diketahui daerah mana yang termasuk obyek dan background dari citra secara jelas. Dimana dua tingkat ditugaskan untuk piksel yang berada dibawah atau diatas nilai ambang batas yang ditentukan. Citra hasil thresholding biasanya digunakan lebih lanjut untuk proses pengenalan obyek serta ekstraksi fitur. Proses thresholding ini pada dasarnya adalah proses pengubahan kuantisasi pada citra, sehingga untuk melakukan thresholding dengan derajat keabuan dapat digunakan persamaan:

$$
\begin{aligned}
& \mathrm{X}=b . \operatorname{int}(w / b) \\
& \mathrm{b}=\operatorname{int}(256 / \mathrm{a})
\end{aligned}
$$

Dimana, w adalah derajat keabuan sebelum thresholding dan $\mathrm{x}$ adalah derajat keabuan setelah thresholding

\section{Metode Korelasi Parametrik}

Metode korelasi parametrik yang memiliki koefisien korelasi ( $r$ ) dapat dianggap sebagai pengukuran yang berguna tentang hubungan antara dua buah variabel missal $\mathrm{X}$ dan Y jika dan hanya jika trend dari titik-titik koordinat dalam diagram pencar membentuk suatu garis linear (Dajan, 1996). Bila trend sedemikian itu berbentuk linier, $r$ yang mendekati nol itu tidak terdapat hubungan antara X dan Y. Dalam hal ini X dan Y dapat dianggap sebagai variabel-variabel yang independen. Pada umumnya hubungan fungsionil antara variabel dan koefisien korelasi tidaklah memberikan dugaan tentang adanya hubungan kausal (causal relation) antara variabel yang bersangkutan. Korelasi dapat dianggap sebagai pengukuran terhadap ko-variasi antara variabel. Misalnya, variabel harga dapat merupakan variabel independen dan digambarkan pada sumbu X sedangkan jumlah permintaan merupakan variabel dependen dan digambarkan pada sumbu Y. Hubungan fungsionil seperti itu merupakan hasil proses pemikiran secara logis dari kita semua yang mengakui adanya hubungan kausal antara kedua variabel tersebut dan adanya pengertian tentang variabel sebab dan variabel mana yang merupakan akibat.

Metode korelasi parametrik dapat dipakai bagi tujuan analisa atau peramalan. Meskipun perubahan dari suatu faktor tudak mengakibatkan perubahan pada faktor lain, tetapi ciri pada kedua variabel dapat membenarkan untuk menari sebuah asumsi tentang adanya hubungan yang fungsionil (Dajan, 1996).

Metode korelasi parametrik sangat bergantung pada koefisien korelasi (r) dan koefisien determinasi $\left(\mathrm{R}^{2}\right)$. Koefisien determinasi tersebut diperoleh melalui persamaan:

$$
r=\frac{n \sum X Y-\sum X \sum Y}{\sqrt{n \sum X^{2}-\left(\sum X\right)^{2}} \sqrt{n \sum Y^{2}-\left(\sum Y\right)^{2}}}
$$

\section{E. Metodologi}

Sistem yang akan dibangun melibatkan dua jenis proses besar yaitu pengukuran langsung terhadap wortel menggunakan perangkat keras dan yang kedua adalah membangun perangkat lunak pengolahan citra wortel. Berdasarkan penelitian yang telah dilakukan oleh (Kurniawan, 2008), (Prasetyani, 2008), dan (Faizal, 2006), sistem informasi pengolahan citra wortel ini dapat berfungsi untuk memperoleh parameter citra wortel yang nantinya akan dibandingkan dengan parameter morfologi dan mutu wortel yang diukur secara langsung. Diharapkan dengan adanya perangkat lunak ini, maka perhitungan parameter yang tadinya manual dapat dilakukan secara otomatis. Perhitungan manual disini maksudnya adalah proses perhitungan parameter diameter dan panjang menggunakan jangka sorong, proses perhitungan parameter berat menggunakan timbangan digital, dan proses perhitungan parameter volume menggunakan gelas ukur. Oleh karena itu, perancangan yang baik diharapkan dapat menghasilkan perangkat lunak yang baik pula.

Sistem informasi klasifikasi wortel ini mempunyai inputan sebuah citra digital hasil pemotretan terhadap wortel yang diletakkan pada ruangan pengambilan citra berukuran 
panjang $80 \mathrm{~cm}$, lebar $80 \mathrm{~cm}$, tinggi $61 \mathrm{~cm}$. Sedangkan output dari perangkat lunak ini adalah parameter citra yang berupa panjang, luas area, dan diameter wortel.

Pengolahan citra wortel ini akan dibagi menjadi 2 subproses yaitu preprocessing dan image analysis. Proses preprocessing sendiri terdiri dari proses thresholding, operasi morfologi, dan proses binerisasi. Sedangkan proses image analysis yaitu mengukur panjang, luas area, dan diameter wortel. Flow sistem yang dibangun ditunjukkan pada Gambar 1.

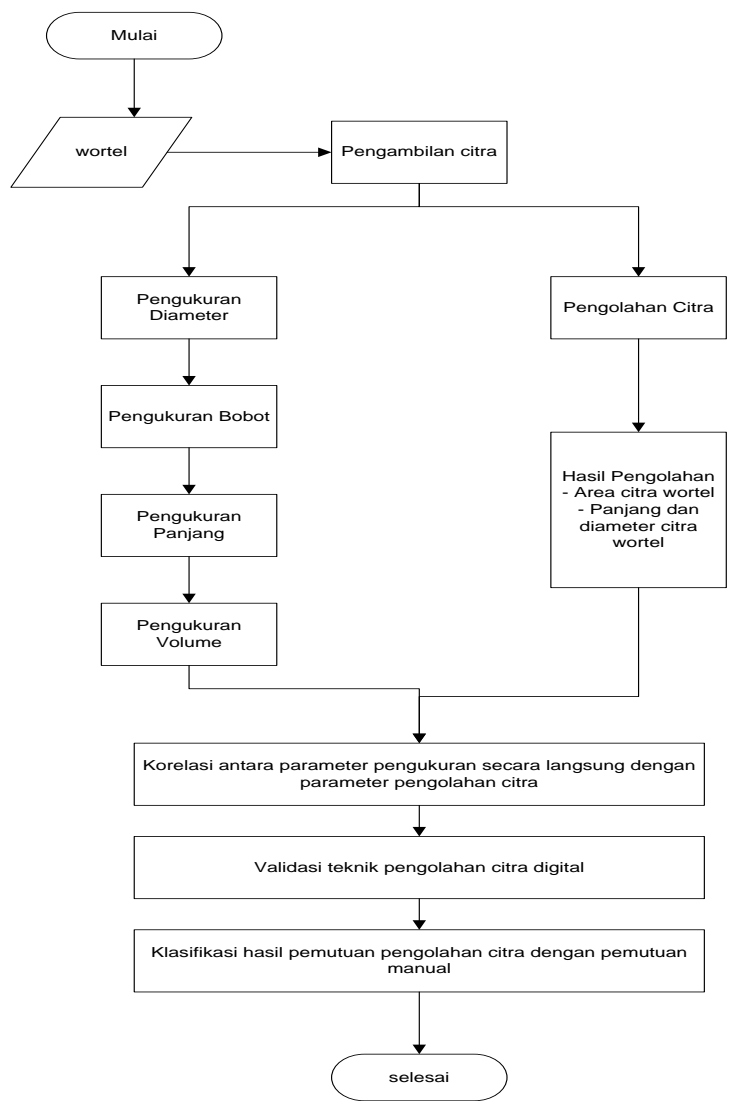

Gambar 1. Flow sistem yang dibangun

\section{F. Alat dan Bahan}

1. Bahan

Bahan yang digunakan pada penelitian ini adalah wortel dengan berbagai ukuran yang merupakan hasil pemutuan secara manual. Wortel varietas lokal yang digunakan sebagai sampel adalah berasal dari Desa Purwosari, Kecamatan Baturraden, kabupaten Banyumas. Total jumlah sampel yang digunakan yaitu sebanyak 85 wortel yang dipilih secara acak.

2. Alat

Perangkat keras yang digunakan untuk pengambilan citra wortel pada penelitian ini yaitu kamera digital, seperangkat laptop, lampu TL 2 buah yang masing-masing memiliki daya 11 watt untuk alat bantu pencahayaan. Selain itu digunakan juga perangkat keras yang digunakan secara langsung untuk mengukur panjang, diameter terbesar wortel dan panjang wortel seperti jangka sorong, gelas ukur, dan timbangan digital. Kain hitam digunakan sebagai penutup ruang pengambilan citra agar cahaya dari luar tidak masuk. Selain itu digunakan juga layar putih sebagai latar belakang pengambilan citra objek. Perangkat keras lainnya adalah luxmeter digital yang digunakan untuk mengatur intensitas cahaya ruang pengambilan citra. Sedangkan perangkat lunak yang digunakan dalam penelitian ini adalah bahasa pemrograman Delphi.

3. Parameter Diameter Wortel

Pengukuran diameter wortel dilakukan dengan menggunakan jangka sorong dengan ketelitian hingga $0.05 \mathrm{~mm}$. Penukuran diameter didasarkan pada besarnya diameter terbesar dari umbi wortel segar. Pengukuran dilakukan dua kali ulangan, kemudian hasil pengukuran dirata-ratakan untuk mendapatkan nilai yang akan digunakan penelitian. Pengukuran diameter wortel ditunjukkan pada Gambar 2.

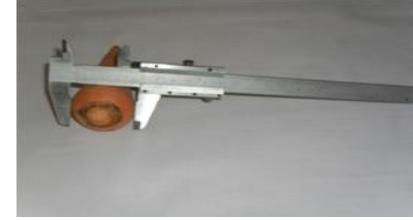

Gambar 2. Pengukuran diameter terbesar wortel.

\section{Parameter Panjang Wortel}

Pengukuran panjang wortel dilakukan dengan menggunakan jangka sorong dengan ketelitian hingga $0.05 \mathrm{~mm}$. Pengukuran panjang dilakukan dari pangkal sampai ujung wortel. Pengukuran dilakukan dua kali ulangan, kemudian hasil pengukuran dirata-ratakan untuk mendapatkan nilai yang akan digunakan penelitian. Pengukuran panjang wortel ditunjukkan pada Gambar 3.

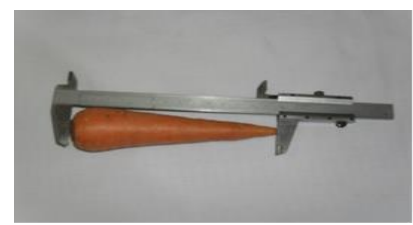

Gambar 3. Pengukuran panjang wortel.

5. Parameter Volume Wortel

Pengukuran wolume wortel dilakukan dengan menggunakan gelas ukur yang 
sebelumnya telah terisi air dengan volume tertentu. Kemudian wortel dimasukkan ke dalamnya hingga posisi wortel terendam sempurna. Lalu diukur penambahan volume air sebelum dan sesudah masuknya wortel. Selisih nilai pengukuran tersebut menunjukkan volume wortel. Pengukuran volume wortel ditunjukkan pada Gambar 4 .

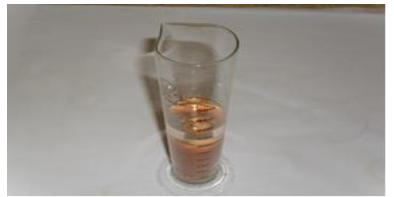

Gambar 4. Pengukuran volume wortel.

6. Parameter Bobot Wortel

Pengukuran bobot wortel dilakukan dengan menggunakan timbangan digital, seperti terlihat pada gambar di bawah ini. Angka yang ditunjukkan timbangan akan digunakan sebagai nilai untuk penelitian. Pengukuran bobot wortel ditunjukkan pada Gambar 5.

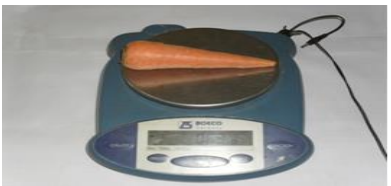

Gambar 5. Pengukuran bobot wortel.

7. Parameter Visual Wortel

Pengukuran area citra wortel dilakukan dengan terlebih dahulu mengubah citra warna menjadi citra biner. Proses ini dilakukan melalui proses thresholding dengan nilai threshold tertentu untuk membedakan citra objek dan latar belakang. Selanjutnya dilakukan perhitungan luas area objek dengan menghitung jumlah piksel dari objek. Proses thresholding, binerisasi, dan operasi morfologi dapat dilihat pada gambar dibawah ini. Proses ditunjukkan pada Gambar 6.

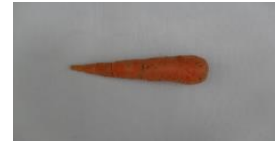

(a)

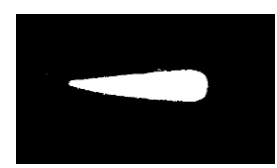

(c)

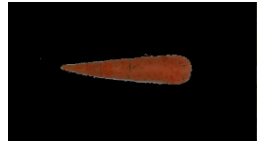

(b)

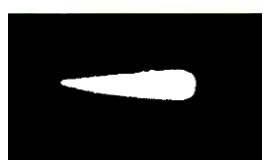

(d)
Gambar 6. Proses thresholding, binerisasi, dan morfologi, (a) citra warna, (b) citra warna yang telah dithresholding, (c) citra biner dengan noise, (d) citra biner bebas noise.

\section{HASIL DAN PEMBAHASAN}

Pada bagian ini akan dijelaskan mengenai hasil pengujian dari sistem informasi klasifikasi wortel dan pembahasannya.

\section{A. Perancangan Sistem}

Untuk mendapatkan parameter visual wortel maka dibangun perangkat lunak dengan menggunakan bahasa pemrograman Delphi 7 . Perangkat lunak ini akan memberikan output berupa area citra objek, panjang citra objek, dan diameter citra objek. Adapun komponen yang ada dalam antarmuka program pengolahan citra wortel adalah button, edit, shape, label, open picure dialog, image, statusbar, groupbox, dan save dialog. Tampilan program ditunjukkan pada Gambar 7.

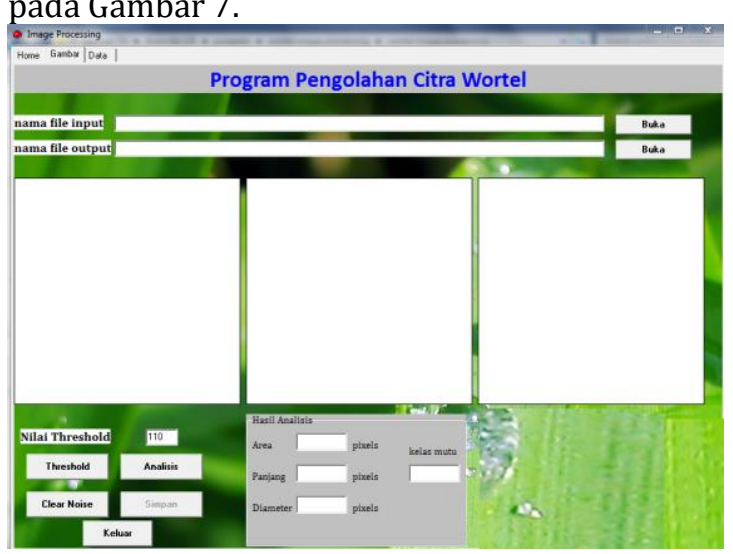

Gambar 7. Tampilan program pengolahan citra wortel

Proses thresholding adalah langkah berikutnya untuk memisahkan antara objek dan latar belakang. Pemilihan nilai threshold disesuaikan sedemikian sehingga objek dapat dipisahkan dengan latar belakangnya. Caranya yaitu dengan menekan button Threshold. Melalui proses ini akan dihasilkan dua buah citra baru yaitu citra warna yang sudah dithreshold dan juga citra biner. Untuk menghasilkan citra biner yang bebas dari noise user dapat langsung menekan button Clear Noise yang terletak di bawah button threshold. Setelah gambar diolah menjadi citra biner yang telah bebas noise maka langkah selanjutnya yaitu menganalisis citra yang ditampilkan program sehingga diperoleh parameterparameter visual berupa citra objek, panjang citra objek, dan diameter citra objek. Caranya yaitu dengan menekan button analisis sehingga dihasilkan angka-angka yang menunjukkan nilai dari masing-masing parameter visual wortel tersebut. Data hasil penyimpanan akan berbentuk file teks pada lokasi tertentu. Tampilan program setelah thresholding dan clear noise ditunjukkan pada Gambar 8. Hasil analisis ditunjukkan pada Gambar 9. 


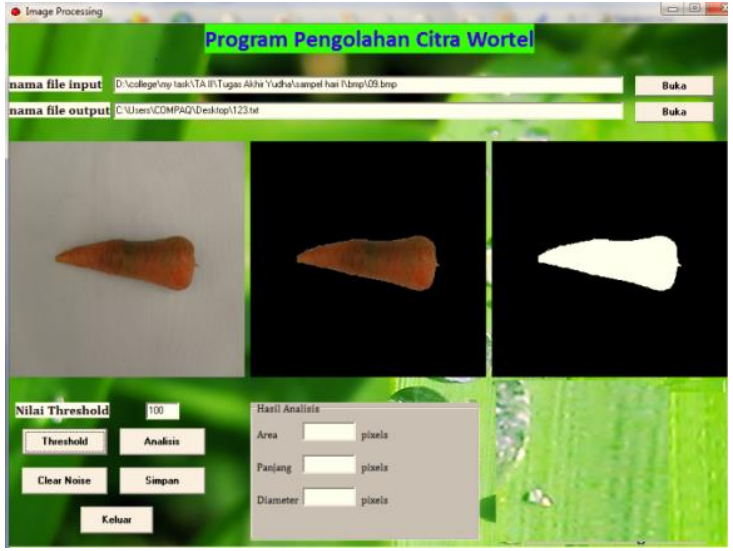

Gambar 8. Tampilan program setelah proses thresholding dan clear noise

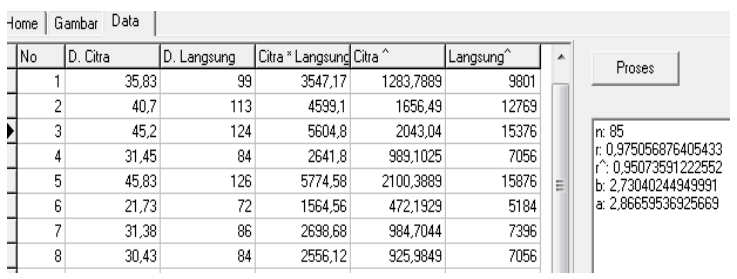

Gambar 9.Tampilan data hasil analisis

\section{B. Klasifikasi Kelas Wortel Menurut SNI} Hasil Pengukuran Langsung dan Citra Wortel dapat diklasifikasikan menurut SNI berdasarkan diameternya. Kriteria klasifikasi wortel dapat dilihat pada Tabel 2 . Hasil klasifikasi kelas secara langsung menurut SNI berdasarkan diameter wortel dari banyaknya sampel 85 wortel adalah sebagai berikut: Terdapat 45 wortel yang masuk kedalam kelas A dan terdapat 40 wortel yang masuk ke dalam kelas $B$, seperti terlihat pada Tabel 2 berikut ini.

Tabel 2. Klasifikasi kelas wortel menurut SNI hasil pengukuran langsung

\begin{tabular}{cc}
\hline $\begin{array}{c}\text { Kelas } \\
\text { Mutu }\end{array}$ & Jumlah Wortel \\
\hline A & 45 \\
B & 40 \\
Total & 85 \\
\hline
\end{tabular}

Tabel 3. Data Pengkelasan dan Tingkat Keberhasilan Pengkelasan Wortel dengan Nilai Threshold yang Berbeda

\begin{tabular}{rrrrrr}
\hline & $\begin{array}{c}\text { A } \\
\text { benar }\end{array}$ & $\begin{array}{c}\text { A } \\
\text { salah }\end{array}$ & $\begin{array}{c}\text { B } \\
\text { benar }\end{array}$ & $\begin{array}{c}\text { B } \\
\text { salah }\end{array}$ & Akurasi \\
\hline Th & & & & & \\
$\mathbf{7 0}$ & 42 & 3 & 40 & 0 & 96.67 \\
$\mathbf{7 5}$ & 44 & 1 & 40 & 0 & 98.88 \\
$\mathbf{8 0}$ & 44 & 1 & 39 & 1 & 97.64 \\
$\mathbf{8 5}$ & 44 & 1 & 38 & 2 & 96.39 \\
\hline
\end{tabular}

Seperti pada Tabel 2, wortel diklasifikasikan menjadi dua kelas berdasarkan diameter, yaitu kelas A dan kelas B. Penggunaan pengolahan citra dalam pengklasifikasian kelas tersebut dapat dilakukan dengan parameter diameter citra. Terlebih dahulu nilai batas parameter diameter wortel dikonversikan ke dalam parameter citra. Kriteria pengklasifikasian wortel berdasarkan diameter menurut SNI dan hasil konversi ke diameter citra untuk nilai threshold 70 dapat dilihat pada Tabel 4 .

Tabel 4. Kriteria Kelas Wortel Menurut SNI Berdasarkan Diameter dan Hasil Konversi ke Diameter Citra (Threshold 70)

\begin{tabular}{ccc}
\hline Kelas & Diameter (mm) & $\begin{array}{c}\text { Diameter } \\
\text { citra } \\
\text { (piksel) }\end{array}$ \\
\hline A & $31-50 \mathrm{~mm}$ & $87-142$ \\
B & $15-30 \mathrm{~mm}$ & $41-85$ \\
\hline
\end{tabular}

Dari hasil perhitungan untuk threshold 70, diperoleh bahwa tingkat keberhasilan pada kelas A adalah sebesar $93.33 \%$ dan kelas B sebesar $100 \%$, atau dengan kata lain tingkat keberhasilan pengklasifikasian ini adalah sebesar $96.67 \%$.

Hasil pengklasifikasian menjelaskan bahwa ada 42 wortel yang masuk ke dalam kelas A sesuai SNI tetapi ada 3 wortel yang tidak tepat, sedangkan dari 40 wortel yang masuk kelas B sesuai SNI semuanya tepat.

Berdasarkan Tabel 3. terlihat bahwa dari keempat nilai threshold yang diujikan, tingkat keberhasilan pengkelasan wortel tertinggi didapat pada nilai threshold 75. Hanya 1 buah wortel yang tidak tepat masuk kelas A. Namun perlu diperhatikan bahwa tingkat keberhasilan rata-rata pengklasifikasian kelas wortel menggunakan pengolahan citra digital pada keempat nilai threshold setelah sebelumnya dilakukan pengujian menggunakan metode korelasi parametrik belum sepenuhnya mencapai 100\%. Hal ini mungkin dikarenakan proses thresholding untuk memperoleh citra biner yang kurang sempurna, sehingga nilai diameter citra yang diperoleh ada yang menjadi tidak sesuai.

\section{KESIMPULAN}

1. Sistem informasi klasifikasi wortel dapat digunakan untuk mendapatkan parameter visual wortel yaitu area citra, panjang citra, dan diameter citra.

2. Diameter citra mempunyai korelasi/keeratan hubungan yang sangat 
kuat terhadap parameter mutu diameter wortel dengan koefisien determinasi $\left(\mathrm{R}^{2}\right)$ sebesar 0.949 pada nilai threshold 70, sebesar 0.951 pada nilai threshold 75, sebesar 0.932 pada nilai threshold 80 , dan pada nilai threshold 85 korelasi yang dihasilkan memiliki hubungan yang kuat dengan koefisien determinasi $\left(\mathrm{R}^{2}\right)$ sebesar 0.864 . Hubungan antara parameter visual wortel dengan parameter morfologi juga memiliki korelasi yang sangat kuat baik panjang wortel dan panjang citra, bobot wortel dan luas bidang proyeksi/area citra, serta volume wortel dan luas bidang proyeksi/area citra. Keeratan hubungan tersebut ditunjukkan dengan koefisien determinasi panjang citra dan panjang wortel sebesar 0.937 pada nilai threshold 70 , sebesar 0.944 pada nilai threshold 75, sebesar 0.942 pada nilai threshold 80, sebesar 0.941 pada nilai threshold 85. Kemudian untuk hubungan parameter luas bidang proyeksi/area citra dan bobot diperoleh koefisien determinasi sebesar 0.939 pada threshold 70 , sebesar 0.939 pada threshold 75, sebesar 0.938 pada threshold 80 , sebesar 0.937 pada threshold 85 . Untuk hubungan parameter luas bidang proyeksi / area citra dan volume diperoleh koefisiendeterminasi sebesar 0.953 pada threshold 70, sebesar 0.954 pada threshold 75 , sebesar 0.953 pada threshold 80 , sebesar 0.952 pada threshold 85 .

3. Wortel dapat dikelaskan berdasarkan diameter sesuai kriteria SNI menggunakan pengolahan citra dengan terlebih dahulu melakukan konversi parameter diameter wortel ke skala citra dengan tingkat skala keberhasilan klasifikasi hingga 96.67 untuk nilai threshold 70, sebesar 98.88 untuk nilai threshold 75, sebesar 97.64 untuk nilai threshold 80, dan sebesar 97.64 untuk nilai threshold 85.

4. Dari keempat nilai threshold yang diuji, nilai threshold 75 memiliki akurasi yang paling baik untuk dipilih karena baik dari tingkat keeratan hubungan maupun tingkat keberhasilan klasifikasi kelas wortel terlihat lebih tinggi.

\section{DAFTAR PUSTAKA}

Ahmad, U. (2005). Pengolahan Citra Digital dan Teknik Pemrogramannya. Yogyakarta: Graha Ilmu.

Anggraeni, C. (2008). Penanganan Pascapanen Wortel (Daucus Carota L.) Tingkat Petani di Desa Serang Kabupaten Purbalingga. Universitas Jenderal Soedirman.

Dajan, A. (1996). Pengantar Metode Statistik jilid II. Jakarta: LP3ES.

Faizal, I. (2006). Aplikasi Image Processing Untuk Pemutuan cabai Merah. Institut Pertanian Bogor. Retrieved from http://repository.ipb.ac.id/jspui/bitstrea m/123456789/61907/8/F10dfi.pdf

Hui, Y. ., Barta, J., Cano, M. P., Gusek, T. W., Sidhu, J., \& Sinhan, N. (2006). Handbook of Fruits and Fruit Processing (1st ed.). WileyBlackwell. Retrieved from https://www.amazon.com/HandbookFruits-Fruit-ProcessingHui/dp/0813819814

Kurniawan, D. (2008). Pra Pengolahan Citra pada Identifikasi Tingkat Kematangan Buah Pisang Mas. Bandung.

Prasetyani, E. (2008). Evaluasi Parameter Pemutuan Buah Stroberi (Fragraria Chiloensis) menggunakan pengolahan citra. Skripsi. Fakultas Teknologi Pertanian. Institut Pertanian Bogor.

Santosa. (2006). Panen dan Pascapanen Wortel. Jurnal Penelitian LUMBUNG, 1, 558-564.

Soekarto. (1990). Dasar-dasar Pengawasan dan Standarisasi Mutu Pangan. Bogor: PAU Pangan dan Gizi IPB.

Whidhiasih, R. N., Wahanani, N. A., \& Supriyanto. (2013). Klasifikasi buah belimbing berdasarkan citra red-greenblue menggunakan knn dan lda. Jurnal Penelitian Ilmu Komputer, System Embedded \& Logic, 1(1), 29-35. https://doi.org/10.1109/CESCE.2010.68

Wiharja, Yanuar Putu; Harjoko, A. (2015). Pemrosesan Citra Digital untuk Klasifikasi Mutu Buah Pisang Menggunakan Jaringan Saraf Tiruan Pemrosesan Citra Digital untuk Klasifikasi Mutu Buah Pisang Menggunakan Jaringan Saraf Tiruan. Ijeis, 4(May 2014), 57-68. 